Volume 4, Number 2, 2018

\title{
Technique for Evaluating the Uncertainty of Enthalpy of Water and Steam for Thermal Energy Metering Systems
}

\author{
Fedir Matiko ${ }^{*}$, Oksana Slabyk, Leonid Lesovoy, Halyna Matiko \\ Lviv Polytechnic National University, 12 S. Bandera St., Lviv, 79013, Ukraine
}

Received: October 18, 2018. Revised: December 06, 2018. Accepted: December 12, 2018.

(C) 2018 The Authors. Published by Lviv Polytechnic National University.

\begin{abstract}
The paper presents an analysis of existing techniques for calculating the enthalpy of water (steam). Based on the analysis the techniques were defined that should be applied for computer-aided design of thermal energy metering systems. Equations for calculating relative expanded uncertainty of water (steam) enthalpy are developed taking into account methodical uncertainty of enthalpy calculation and uncertainties of metering temperature and pressure of water (steam). Simplified dependencies are developed for calculating the relative sensitivity coefficients of the enthalpy uncertainty to the uncertainties of water pressure and temperature. These dependencies make it possible to calculate the values of the sensitivity coefficients for a range of pressure from 0 to $5 \mathrm{MPa}$ and temperature from 300 to $550 \mathrm{~K}$. The relative deviations of the sensitivity coefficients obtained by the simplified dependencies from the values obtained by the equations of International Association for the Properties of Water and Steam (IAPWS) are $0.48 \%$ (for the sensitivity coefficient of uncertainty of enthalpy to uncertainty of pressure) and $0.56 \%$ (for the sensitivity coefficient of uncertainty of enthalpy to uncertainty of temperature) for the above pressure and temperature ranges. The developed simplified technique for evaluating uncertainty of water (steam) enthalpy can be applied to determine the metrological characteristic of thermal energy metering systems and also for their computer-aided design.
\end{abstract}

Keywords: water enthalpy; uncertainty of enthalpy; technique for evaluating uncertainty; sensitivity coefficient; thermal energy amount.

\section{Definition of the problem to be solved}

Modern microprocessor thermal energy metering systems make it possible to realize the real-time measuring thermal energy amount taking into account thermo-physical parameters of a heat carrier. Today water (steam) is the most common and available heat carrier in heat supply systems. In most thermal energy metering systems the thermodynamic parameters of water (steam) are calculated in real-time based on measured pressure and temperature. Respectively thermal energy amount is calculated using the calculated values of heat carrier parameters and the measured values of the flow parameters [1,2].

The influence of uncertainties of calculating the thermo-physical parameters of a heat carrier on the uncertainty of the thermal energy amount can be significant in the case of such a method is used for thermal energy metering systems.

It is necessary to evaluate the uncertainty of thermo-physical parameters of water (steam) in order to use these measured results in thermal energy metering systems. The equations for calculating uncertainty of enthalpy obtained on the basis of the dependencies in [3,4] are very complicated. Therefore, simplifying the dependencies for evaluating uncertainty of enthalpy and their application for evaluating uncertainty of thermal energy amount is a relevant problem.

"Corresponding author. Email address: fmatiko@gmail.com

This paper should be cited as: F. Matiko, O. Slabyk, L. Lesovoy, H. Matiko. Technique for evaluating the uncertainty of enthalpy of water and steam for thermal energy metering systems. Energy Eng. Control Syst., 2018, Vol. 4, No. 2, pp. 79 - 86. https://doi.org/10.23939/jeecs2018.02.079 


\section{Analysis of the recent publications and research works on the problem}

The investigations of thermo-physical properties of water and steam have been conducting in different countries for many years. They are coordinated by International Association for the Properties of Water and Steam (IAPWS). This organization analyzes the obtained experimental data on the basis of which international normative documents are developed.

In 1995, International Association for the Properties of Water and Steam developed an equation for calculating the specific free energy of Helmholtz [3]. This equation is used to calculate the thermodynamic parameters of water and steam for scientific purposes in such ranges of pressure and temperature: $0<p<1000 \mathrm{MPa}$ and $-38.15<t<1000{ }^{\circ} \mathrm{C}$.

In 1997, the International Association for the Properties of Water and Steam developed a new equation for calculating the specific free energy of Helmholtz and Gibbs [4]. This equation makes it possible to calculate the thermodynamic parameters of water and steam for engineering purposes in the ranges of pressure $0<p<100 \mathrm{MPa}$, $100<p<10 \mathrm{MPa}$ and in the ranges of temperature $0<t<800{ }^{\circ} \mathrm{C}, 800<t<2000{ }^{\circ} \mathrm{C}$, respectively. However, these equations for calculation of water (steam) properties in $[3,4]$ are too complicated and it is necessary to work out large arrays of coefficients. So they can be implemented only by using microprocessor devices with large computing capacities.

The document GSSSD 187-99 [5] contains a technique for calculating enthalpy of water (steam) on the base of equations [3] and the tables of enthalpy and absolute error of enthalpy for a range of temperature from 0 to $1000{ }^{\circ} \mathrm{C}$ and pressure from 0.001 to $1000 \mathrm{MPa}$. However application of these tables in computer-aided design is inconvenient and leads to the additional errors of enthalpy.

In the technique MI 2412-97 [6], a simplified equation for calculating enthalpy of water (steam) is used. The error of enthalpy calculated by this equation is determined relatively to table values [5]. The comparison of enthalpy values [5] and enthalpy calculated by equations [4] is presented in table 1.

Table 1. The comparison of enthalpy values calculated by the formulas IAPWS 97 [2], Recommendations on metrology MI 2412-97 RF 1997 [6] and State Standard of Russia GSSSD 187-99 [5].

\begin{tabular}{|c|c|c|c|c|}
\hline \multicolumn{2}{|c|}{$\begin{array}{c}\text { Temperature } \\
\text { and absolute pressure }\end{array}$} & \multicolumn{3}{|c|}{ Enthalpy, $\mathrm{KJ} / \mathrm{kg}$} \\
\hline$T, \mathrm{~K}$ & $p, \mathrm{MPa}$ & IAPWS 97 & GSSSD 187-99 & MI 2412-97 \\
\hline 323.15 & 0.5 & 209.76 & 209.75 & 209.75 \\
\hline 348.15 & 1 & 314.75 & 314.73 & 314.87 \\
\hline 373.15 & 0.5 & 419.4 & 419.36 & 419.45 \\
\hline 423.15 & 1 & 632.57 & 632.6 & 632.11 \\
\hline
\end{tabular}

Table 1 shows that there is a small difference between enthalpy values calculated by the given techniques. Therefore the equations given in $[4,6]$ should be applied for computer-aided design of thermal energy metering systems.

However for their application in the computer-aided design of thermal energy metering systems it is necessary to develop the technique for calculating uncertainty of enthalpy that takes into account the influence of uncertainties of water (steam) pressure and temperature.

\section{Formulation of the goal of the paper}

The goal of this paper is to develop a simplified technique for evaluating uncertainty of enthalpy of water (steam) taking into account the influence of uncertainties of the state parameters of the heat carrier (pressure, temperature).

\section{Developing the technique for evaluating the uncertainty of water (steam) enthalpy}

The following equation [7] is used for calculating the thermal energy amount produced by the source or used by the consumer:

$$
W=\sum_{i=1}^{a} \int_{t_{0}}^{t_{k}} Q_{1 i} \cdot h_{1 i} \cdot d t-\sum_{j=1}^{b} \int_{t_{0}}^{t_{k}} Q_{2 j} \cdot h_{2 j} \cdot d t-\sum_{p=1}^{m} \int_{t_{0}}^{t_{k}} Q_{f p} \cdot h_{f p} \cdot d t,
$$


where $Q_{l i}, Q_{2 i}$ are the flowrates of heat carrier in each supply and reverse pipeline;

$h_{l i}$ is a specific enthalpy of heat carrier in each supply pipeline, $h_{l}=f\left(T_{s p}, P_{s p}\right)$;

$h_{2 i}$ is a specific enthalpy of heat carrier in each reverse pipeline, $h_{2}=f\left(T_{r p}, P_{r p}\right)$;

$a$ is a number of supply pipelines;

$b$ is a number of reverse pipelines;

$m$ is a number of metering units of feeding pipelines;

$Q_{f p}$ is a mass flowrate of heat carrier used for feeding the system in each feeding pipeline;

$h_{f p}$ is a specific enthalpy of cold water in each feeding pipeline.

The equation (1) shows that the flowrate and the enthalpy of water (steam) are the important parameters for determining the amount of thermal energy that should be taken into consideration. The technique for calculating the flowrate of water (steam) measured by differential pressure devices is presented in [9].

The enthalpy of water (steam) characterises amount of heat which is carried by the unit of water (steam) mass. In accordance with IAPWS97 [4] specific enthalpy $h$ is calculated on the basis of equation for free energy by Gibbs (for $\left.273.15 \mathrm{~K}<T<623.15 \mathrm{~K} ; P_{s} \leq p \leq 100 \mathrm{MPa}\right)$ :

$$
\begin{gathered}
\frac{g(p, T)}{R T}=\gamma(\pi, \tau)=\sum_{i=1}^{34} n_{i}(7.1-\pi)^{I_{i}}(\tau-1.222)^{J_{i}} ; \\
h=g-T(\partial g / \partial T)_{p} ; \\
h(\pi, \tau)=1386 R \gamma_{\tau},
\end{gathered}
$$

where $\pi$ is a pseudo-reduced pressure: $\pi=p / P^{*}$;

$p$ is a absolute pressure of water, MPa;

$P^{*}$ is a pseudo-critical pressure (for the specified range $P^{*}=16.53 \mathrm{MPa}$ );

$\tau$ is a pseudo-reduced temperature: $\tau=T^{*} / T$;

$T$ is a thermodynamic temperature of water, $\mathrm{K}$;

$T^{*}$ is a pseudo-critical temperature (for the specified range $T^{*}=1386 \mathrm{~K}$ );

$R$ is a universal gas constant for water: $\mathrm{R}=0.461526 \mathrm{~kJ} /(\mathrm{kg} \cdot \mathrm{K})$;

$\gamma_{\tau}$ is a partial derivative of enthalpy by temperature which is calculated by the following equation

$$
\gamma_{\tau}=\sum_{i=1}^{34} n_{i}(7.1-\pi)^{I_{i}} J_{i}(\tau-1.222)^{J i-1},
$$

where $I_{i}, J_{i}, n_{i}$ are the constant coefficients for the range $273.15 \mathrm{~K}<T<623.15 \mathrm{~K} ; P_{s} \leq p \leq 100 \mathrm{MPa}$ [4].

In order to control the range of application of equations (2)-(4), it is necessary to know a pressure $P_{s}$ of dry saturated steam. Dry saturated steam is characterized by dependence between pressure and temperature of water (steam) that is the line of saturation. The state of dry saturated steam is an idealized state because it is impossible to achieve the stationary state of medium at the saturation line (it turns to the zone of moist water steam with decrease in steam temperature and it turns to the zone of overheated steam with increase in steam temperature at the same pressure).

The pressure of dry saturated steam can be determined by solving the equation which describes the saturation line of dry steam and unites relative pressure $\beta$ with relative temperature $\vartheta$ [4]:

$$
\beta^{2} \vartheta^{2}+n_{1} \beta^{2} \vartheta+n_{2} \beta^{2}+n_{3} \beta \vartheta^{2}+n_{4} \beta \vartheta+n_{5} \beta+n_{6} \vartheta^{2}+n_{7} \vartheta+n_{8}=0
$$

To do this, the equation (6) has to be solved relatively variable $\beta=\left(\frac{P_{s}}{P^{*}}\right)^{1 / 4}[4]$ : 


$$
\begin{gathered}
\frac{P_{s}}{P^{*}}=\left[\frac{-B-\left(B^{2}-4 A C\right)^{1 / 2}}{2 A}\right]^{4}, \\
A=\vartheta^{2}+n_{1} \vartheta+n_{2} ; B=n_{3} \vartheta^{2}+n_{4} \vartheta+n_{5} ; C=n_{6} \vartheta^{2}+n_{7} \vartheta+n_{8},
\end{gathered}
$$

where $P^{*}$ is a pseudo-critical pressure that equals $1 \mathrm{MPa}$;

$n_{i}$ are the constant coefficients for a range of dry saturated steam [4];

$\vartheta$ is a relative temperature:

$$
\vartheta=\frac{T_{s}}{T^{*}}+\frac{n_{9}}{\frac{T_{s}}{T^{*}}-n_{10}},
$$

where $T^{*}$ is a pseudo-critical temperature, it equals $1 \mathrm{~K}$ for a range of dry saturated steam;

$T_{s}$ is a temperature of dry saturated steam. equation:

The temperature of dry saturated steam is determined as a function of the saturated steam pressure by the

$$
\frac{T_{s}}{T^{*}}=\frac{n_{10}+D-\left[\left(n_{10}+D\right)^{2}-4\left(n_{9}+n_{10} D\right)\right]^{1 / 2}}{2}
$$

where

$$
\begin{gathered}
E=\beta^{2}+n_{3} \beta+n_{6} ; \quad F=n_{1} \beta^{2}+n_{4} \beta+n_{7} ; G=n_{2} \beta^{2}+n_{5} \beta+n_{8} ; \\
D=\frac{-F+\left(F^{2}-4 E G\right)^{1 / 2}}{2 E} .
\end{gathered}
$$

Equations (6)-(10) describe the area of dry saturated steam which is determined by the following pressure and thermodynamic temperature ranges:

$$
\text { 273.15 K } \leq T_{s} \leq 647.096 \mathrm{~K} ; \quad 611.213 \mathrm{~Pa} \leq P_{s} \leq 22.064 \mathrm{MPa} .
$$

The equations (3), (4) show that enthalpy is a thermodynamic function of water (steam) pressure and temperature. The enthalpy is determined by indirect method on the basis of the measured values of water (steam) pressure and temperature.

The relative expanded uncertainty $U_{y}^{\prime}$ of the parameter $y$ related to the measured parameters $y_{i}$ by functional dependence $y=F\left(y_{1}, y_{2}, \ldots, y_{n}\right)$ is calculated by the following equation [8]

$$
U_{y}^{\prime}=\left[U_{M F}^{\prime 2}+\sum_{i}^{n} F_{y_{i}}^{2} U_{y_{i}}^{\prime 2}\right]^{0.5}
$$

where $U_{M F}^{\prime}$ is a relative methodical uncertainty of the dependence;

$U_{y i}^{\prime}$ is an uncertainty of the measurement result of the $i$-th parameter;

$F_{y i}$ is a relative sensitivity coefficient of parameter $y$ to the change of the $i$-th measured parameter.

The relative sensitivity coefficient should be determined by the equation

$$
F_{y_{i}}=\vartheta_{y_{i}}^{\prime} \frac{y_{i}}{y}
$$

where $\vartheta_{y_{i}}^{\prime}$ is a partial derivative of function $F$ by parameter $y_{i}$. 
Applying the equation (11) to the dependence of enthalpy on pressure and temperature of water (steam) $h=F(p, T)$ we obtain the equation of relative uncertainty of enthalpy

$$
U_{h}^{\prime}=\left[U_{M h}^{\prime 2}+\left(F_{h T} U_{T}^{\prime}\right)^{2}+\left(F_{h p} U_{p}^{\prime}\right)^{2}\right]^{0.5},
$$

where $U_{M h}^{\prime}$ is a methodical uncertainty of the dependence $h=F(p, T)$; there are no values of methodical uncertainty of enthalpy in the document IAPWS [4] but it is known that this uncertainty is less than uncertainty of isobar heat capacity which is equal to $0.3 \%$, so we consider $U_{M h}^{\prime}=0.3 \%$ in this paper;

$U_{T}^{\prime}$ is a relative expanded uncertainty of water (steam) temperature;

$U_{p}^{\prime}$ is a relative expanded uncertainty of water (steam) pressure.

$F_{h T}$ is a relative sensitivity coefficient of the uncertainty of enthalpy to the uncertainty of water (steam) temperature;

$F_{h p}$ is the relative sensitivity coefficient of the uncertainty of enthalpy to the uncertainty of water (steam) pressure.

The relative sensitivity coefficients $F_{h T}, F_{h p}$ can be determined by equations (14), (16) developed by the authors on the basis of the partial derivative equations given in [4]:

$$
\begin{gathered}
F_{h T}=\frac{\partial h}{\partial \tau} \cdot \frac{\tau}{h}=\frac{\tau \gamma_{\tau \tau}}{\gamma_{\tau}} ; \\
\gamma_{\tau \tau}=\sum_{i=1}^{34} n_{i}(7.1-\pi)^{I_{i}} J_{i}\left(J_{i}-1\right)(\tau-1.222)^{J_{i-2}}, \\
F_{h p}=\frac{\partial h}{\partial \pi} \cdot \frac{\pi}{h}=\frac{\pi \gamma_{\pi \tau}}{\gamma_{\tau}} ; \\
\gamma_{\pi \tau}=\sum_{i=1}^{34}-n_{i} I_{i}(7.1-\pi)^{I_{i}-1} J_{i}(\tau-1.222)^{J_{i-1}},
\end{gathered}
$$

Verification of realization of the algorithm of enthalpy calculating by the equations (3), (4) comparatively to the results of control calculations given in [4] proved their complete convergence (see table 2). In such a way we also proved the reliability of the values of enthalpy uncertainty calculated by the equation (13) (see table 2).

Table 2. The enthalpy and relative expanded uncertainty of water (steam) enthalpy.

\begin{tabular}{|c|c|c|}
\hline $\begin{array}{c}\text { Temperature } \\
\text { and absolute pressure }\end{array}$ & $h, \mathrm{~kJ} / \mathrm{kg}$ & $U_{h}^{\prime}, \mathrm{kJ} / \mathrm{kg}$ \\
\hline $\begin{array}{c}T=300 \mathrm{~K} \\
p=3 \mathrm{MPa}\end{array}$ & $0.115331273 \times 10^{3}$ & 1.834 \\
\hline $\begin{array}{c}T=500 \mathrm{~K} \\
p=4 \mathrm{MPa}\end{array}$ & $0.975761419 \times 10^{3}$ & 0.383 \\
\hline $\begin{array}{l}T=350 \mathrm{~K} \\
p=1 \mathrm{MPa}\end{array}$ & $0.322501226 \times 10^{3}$ & 0.716 \\
\hline
\end{tabular}

It is necessary to calculate the sensitivity coefficients by equations (14) and (16) in order to calculate the enthalpy uncertainty by equation (13). It needs complex calculations using the arrays of coefficients $I, J, n$ given in [4] and the control of application range of equations (2)-(4), (5), (15), (17) with the help of determining steam pressure and temperature at the saturation line by the equation (6). Therefore, it is advisable to develop simplified dependencies for calculating the coefficients $F_{h T}$ and $F_{h p}$.

We analysed the dependences $F_{h T}=F_{1}(p, T)$ and $F_{h p}=F_{2}(p, T)$ (see Fig.1) and established that the dependence $F_{h T}=F_{l}(p, T)$ can be reproduced only by temperature dependence with the sufficient accuracy for practical tasks. The dependence $F_{h p}=F_{2}(p, T)$ should take into account both the changes of heat carrier temperature and pressure. 

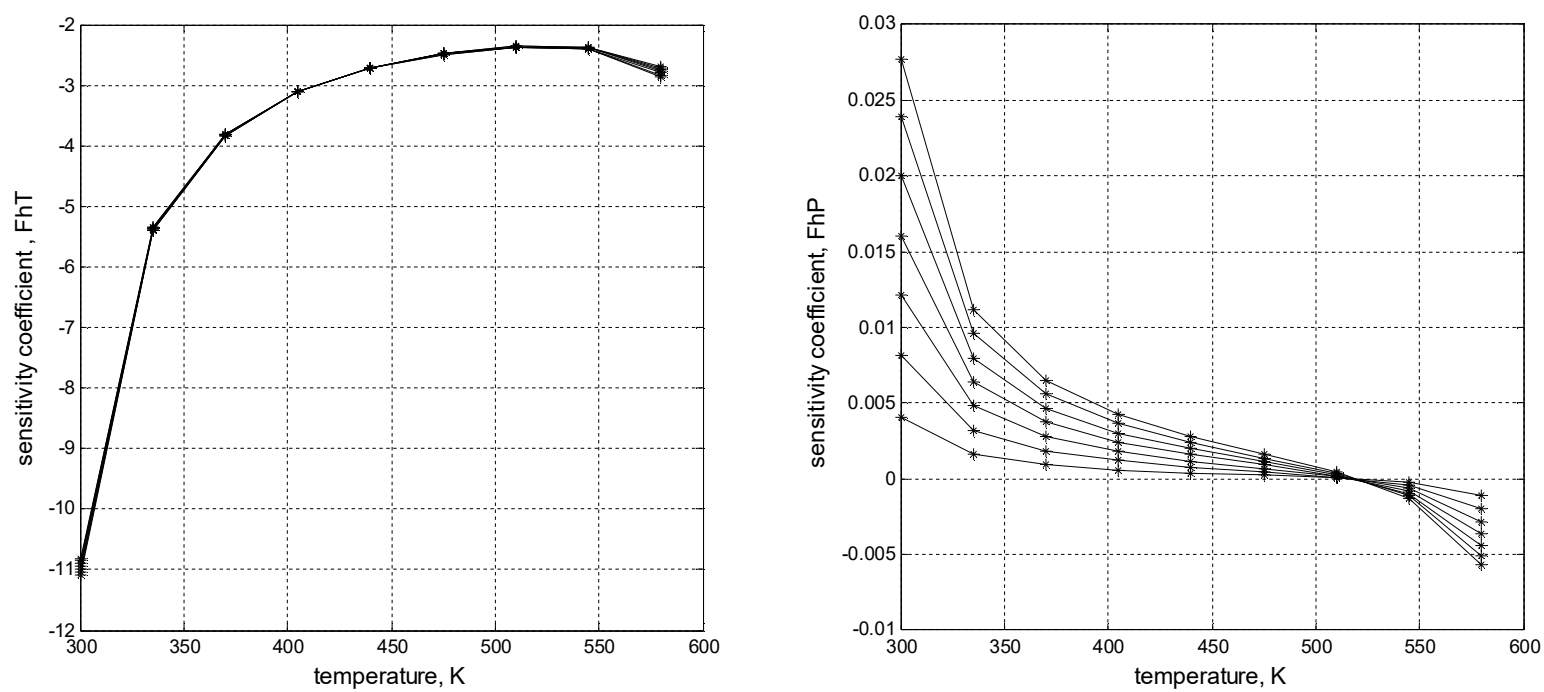

Fig.1 The coefficients $F_{h T}$ and $F_{h p}$ versus the temperature of heat carrier for fixed pressure values in the range from $0.5 \mathrm{MPa}$ to $5 \mathrm{MPa}$.


Fig. 2 The dependencies of coefficients $F_{h T}$ and $F_{h p}$ versus the pressure of the heat carrier.

Simplified dependencies are developed by approximating the values $F_{h T}, F_{h p}$ calculated by the equations (14), (16) in the form of cubic polynomial (see Fig.3 and Fig.4). The polynomial coefficients were defined by least squares method:

$$
\begin{gathered}
F_{h T}=1.3471 \Theta^{3}-19.8754 \Theta^{2}+96.8585 \Theta-158.4162, \\
F_{h p}=0.06 p\left(-0.0265 \Theta^{3}+0.3695 \Theta^{2}-1.7163 \Theta-2.6647\right), \Theta=T / 100, K .
\end{gathered}
$$

The relative deviations of the values $F_{h T}, F_{h p}$ obtained by (18), (19) from the values obtained by (14), (16) are equal to $0.48 \%$ and $0.56 \%$ respectively for the temperature range from $300 \mathrm{~K}$ to $550 \mathrm{~K}$.

The equations (13), (18), (19) serve as the basis for the simplified technique for evaluating the uncertainty of enthalpy of water (steam) which can be applied for evaluating the metrological characteristics of thermal energy metering systems and also for their computer-aided design. 


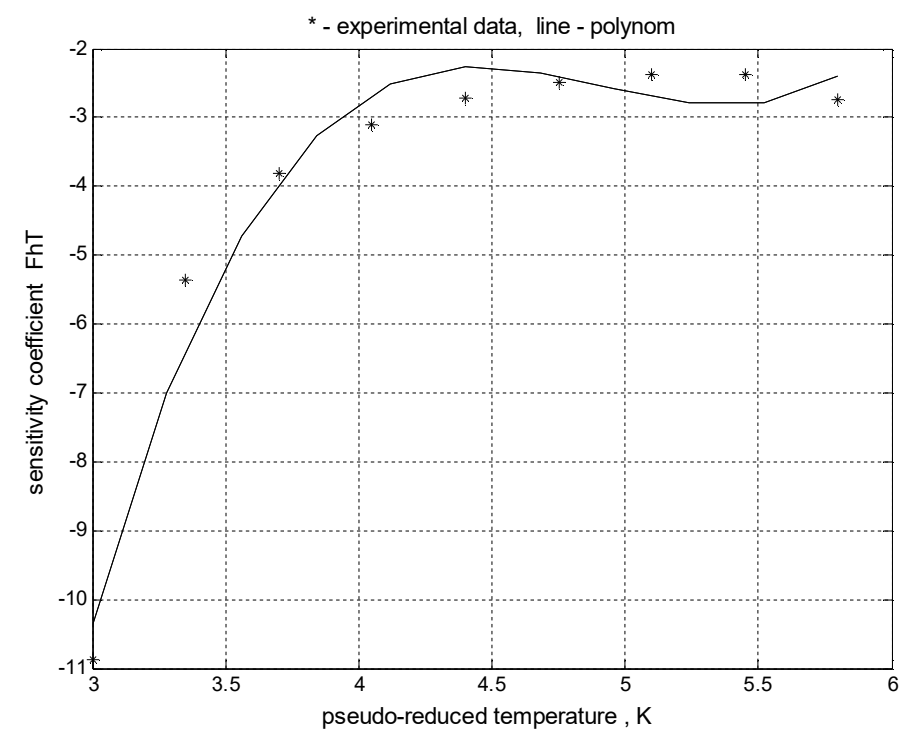

Fig. 3 Averaged value of sensitivity coefficient $F_{h T}$ versus the heat carrier temperature.

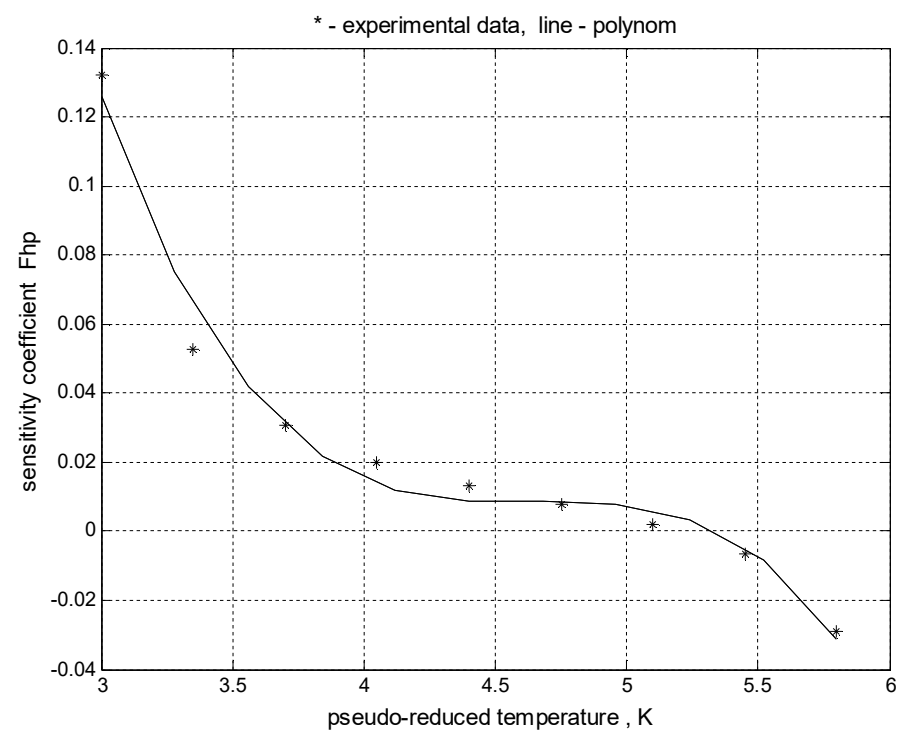

Fig. 4 Averaged value of sensitivity coefficient $F_{h p}$ versus the heat carrier temperature.

\section{Conclusion}

1) The analysis of the existing techniques $[4-6,1]$ for calculating the enthalpy of water (steam) showed that the equations presented in [4], [6] should be applied for computer-aided design of thermal energy metering systems.

2) The developed equation (13) for calculating the relative expanded uncertainty of the enthalpy of water (steam) taking into account the methodical uncertainty of enthalpy and the uncertainties of temperature and pressure of water (steam) is the basis for the technique for evaluating uncertainty of enthalpy. It can be applied for every equation for calculating enthalpy.

3) The authors developed the simplified dependencies for determining sensitivity coefficients of the uncertainties of water (steam) temperature and pressure to the uncertainty of enthalpy for the ranges of pressure from 0 to $5 \mathrm{MPa}$ and temperature from 300 to $550 \mathrm{~K}$.

Application of the developed simplified technique for evaluating the uncertainty of water (steam) enthalpy makes it possible to simplify the algorithms of computer-aided design of thermal energy meters. 


\title{
References
}

[1] GOST 8.728-2010 State system for ensuring the uniformity of measurements. Estimation of errors of measurements of thermal energy and weight of the heat-carrier of water systems of the heat supply. D.I. Mendeleyev Institute for Metrology. (in Russian)

[2] Celenza, L., Dell'Isola, M., Ficco, G., Vigo, P., Pauletti, L. (2015) Metrological characterization of a new direct heat accounting device. AISEM Annual Conference, XVIII. https://doi.org/10.1109/AISEM.2015.7066816

[3] Release on the IAPWS Industrial Formulation 1995 for the Thermodynamic Properties of Ordinary Water Substance for General and Scientific Use. International Association for the Properties of Water and Steam, http://www.iapws.org

[4] Release on the IAPWS Industrial Formulation 1997 for the Thermodynamic Properties of Water and Steam. International Association for the Properties of Water and Steam, http://www.iapws.org

[5] Aleksandrov A.A., Grygoriev B.A. GSSSD 187-99. Tables of Standard Reference Data. Ordinary water specific volume and enthalpy in the temperature range 0 to $1000^{\circ} \mathrm{C}$ and the pressure range 0.001 to $1000 \mathrm{MPa}$. (in Russian)

[6] MI 2412-97 Recommended Practice - National Measurement Standards - Piped Hot Water Heat Supply Systems - Equations for Measurement of Thermal Energy and Quantity of Heat Transfer Agent. D.I. Mendeleyev Institute for Metrology. (in Russian)

[7] Matiko, F. D., Slabyk, O. M., Hutnyk, M. B. (2018) Analysis of normative base for systems of measuring the amount of thermal energy. Scientific Bulletin of UNFU, Vol. 28, No 3, 105-110. https://doi.org/10.15421/40280322 (in Ukrainian)

[8] JCGM 100:2008, GUM 1995 with minor corrections Evaluation of measurement data - Guide to the expression of uncertainty in measurement.

[9] Lesovoy L. V. (2011) Calculation of the flowrate of the humid water steam by method of the differential pressure with standard primary device. Quality Control Tools and Techniques, Vol. 1, No. 26, 71-76. (in Ukrainian)

\section{Методика оцінювання невизначеності ентальпії води та водяної пари для систем вимірювання кількості теплової енергії}

\author{
Федір Матіко, Оксана Слабик, Леонід Лесовой, Галина Матіко \\ Національний університет «Львівська політехніка», вул. С. Бандери, 12, м. Львів, 79013, Україна
}

\section{Анотація}

В статті представлено аналіз існуючих методик розрахунку ентальпії води (водяної пари), за результатами якого визначено методики, які доцільно застосовувати для автоматизованого проектування систем обліку теплової енергії. Розроблено рівняння для розрахунку відносної розширеної невизначеності ентальпії води (водяної пари) із врахуванням методичної невизначеності обчислення ентальпії та невизначеностей результатів вимірювання температури та тиску води (водяної пари). Розроблено спрощені аналітичні залежності для обчислення відносних коефіцієнтів чутливості невизначеності ентальпії до невизначеності результатів вимірювання тиску та температури води. Ці залежності дають можливість обчислити значення коефіцієнтів чутливості для діапазону тиску від 0 до 5 МПа та температури від 300 до $550 \mathrm{~K}$. Відносні відхилення значень коефіцієнтів чутливості, отриманих за спрощеними залежностями, від значень, отриманих за рівняннями Міжнародної організації властивостей води та водяної пари (IAPWS), у вказаних діапазонах тиску та температури становлять відповідно 0,48\% (для коефіцієнта чутливості невизначеності ентальпії до невизначеності тиску) і $0,56 \%$ (для коефіцієнта чутливості невизначеності ентальпії до невизначеності температури). Розроблена спрощена методика оцінювання невизначеності ентальпії води (водяної пари) може бути застосована під час оцінювання метрологічних характеристик систем вимірювання кількості теплової енергії а також для їх автоматизованого проектування.

Ключові слова: ентальпія води; невизначеність ентальпії; методика оцінювання невизначеності; коефіцієнт чутливості; кількість теплової енергії. 